\title{
Transatlantica
}

Revue d'études américaines. American Studies Journal

$2 \mid 2013$

Jeux et enjeux du texte

\section{Interview with Ellen Gruber Garvey}

\section{Claire Parfait}

\section{OpenEdition}

Journals

Electronic version

URL: https://journals.openedition.org/transatlantica/6752

DOI: 10.4000/transatlantica.6752

ISSN: 1765-2766

\section{Publisher}

Association française d'Etudes Américaines (AFEA)

Printed version

Date of publication: 31 December 2013

\section{Electronic reference}

Claire Parfait, "Interview with Ellen Gruber Garvey", Transatlantica [Online], 2 | 2013, Online since 17

April 2014, connection on 03 February 2023. URL: http://journals.openedition.org/transatlantica/6752 ; DOI: https://doi.org/10.4000/transatlantica.6752

This text was automatically generated on 3 February 2023.

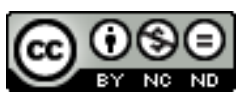

Creative Commons - Attribution-NonCommercial-NoDerivatives 4.0 International - CC BY-NC-ND 4.0 https://creativecommons.org/licenses/by-nc-nd/4.0/ 


\title{
Interview with Ellen Gruber Garvey
}

\author{
Claire Parfait
}

1 Ellen Gruber Garvey is the author of Writing with Scissors: American Scrapbooks from the Civil War to the Harlem Renaissance (Oxford University Press, 2013). She was a Visiting Professor at Université Paris 13 in November 2013. She teaches at New Jersey City University. She was interviewed by Claire Parfait (Université Paris 13) on November 26, 2013.

\section{Claire Parfait: What gave you the idea to start working on scrapbooks?}

Ellen Gruber Garvey: I had looked at children's scrapbooks, where children saved advertising cards and then arranged them on the page for my first book, The Adman in the Parlor: Magazines and the Gendering of Consumer Culture, 1880s-1910s (Oxford University Press, 1996), so I was interested in that idea that you could see something about people's responses to what they read by how they pasted it down on the page. At the same time I read quite a lot about what 19th-century people thought about scrapbooks and about collecting. And because I had this interest in scrapbooks, when I went into a used book store once, the proprietor, who turned out to be a retired English professor, showed me a book. She said "Have you ever seen anything that looks like this?" 


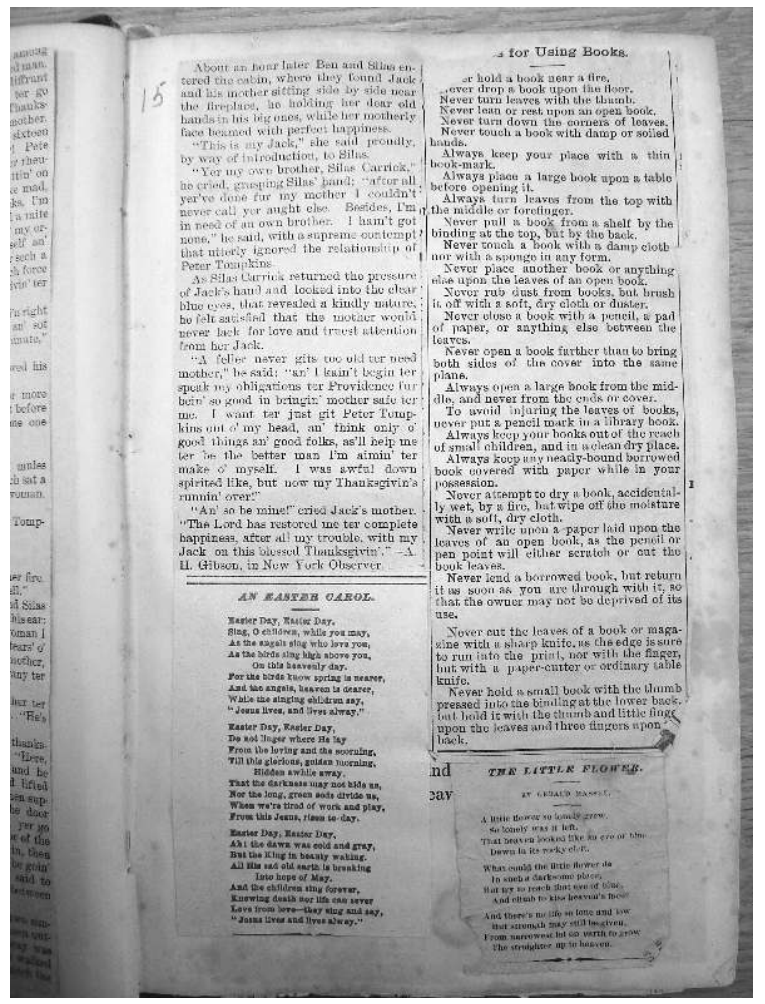

Scrapbook of clippings pasted over a book of sermons, Richard Baxter's Saint's Everlasting Rest, includes a list of "hints on using books," cautioning against holding a book too close to the fire or marking on it. It suggests that the scrapbook maker valued books, and the seriousness they accorded her clippings. (Collection of the author.)

It was a book of Puritan sermons, Saints' Everlasting Rest, by Richard Baxter, who was Oliver Cromwell's chaplain. Inside it though, instead of Puritan sermons, were pasted down clippings of short stories and poems. I was completely blown away. The first story that started it off was an 1880s story by Mary Wilkins Freeman, "The Revolt of Mother." In that story is a farm woman, whose husband has kept them living in a decrepit falling down house for 40 years refusing to build a new one while he puts up new barns. When he goes away for a couple of days to buy more cows, she moves the family into a fresh new barn which is much nicer than their house. So I realized that there was this wonderful parallel with the scrapbook maker who had moved her shabby clippings from the newspaper into a nice substantial book of Puritan sermons, which she had pasted over. Now, whether she was really critical of the sermons, or whether she just didn't care about them or she really wanted a scrapbook, I don't know. She didn't articulate that much, but at least we can see that she didn't care about the sermons. That much is clear.

Then I discovered that actually this was a very common practice, to paste over existing books, to paste over old ledger books; and it meant that scrapbooks were a really democratic archive, because anybody could afford to make them. It didn't require any substantial outlay at all. In fact there were many kinds of books that were even given out free by the government, agricultural reports and the patent office reports, very nice looking, substantial, well-bound books. You could get them for free and then turn them into a scrapbook-why not? In fact articles that advised people about making scrapbooks suggested that these were good things to get and turn into scrapbooks. So I have some funny stories about that in the book. 
And people bought scrapbooks too. In fact Mark Twain invented a kind of scrapbook which I discuss in more depth there. It's tied together with the history of recirculation and literary piracy. But really, scrapbook-making was very widely distributed. Thousands of Americans made scrapbooks in the 19th century: both men and women. Nowadays people think of scrapbooking as just something that women do, but 19th-century scrapbooks were really much more records; they were methods of record keeping and they had business applications, and they were statements. Public speakers made them. They were something that just was part of ordinary life, of business as well. And so, they're all over the place.

CP: How do you explain that craze? Can you say a little of what you say in the book, about the multiplication of cheap papers, and the link between cheap papers and scrapbooks?

EG: Starting in the 1830s, you have the penny press in the United States, and that really takes off, and circulations go way up as the century moves on. There are a number of watershed moments of higher circulation for newspapers. One of them is the Civil War.

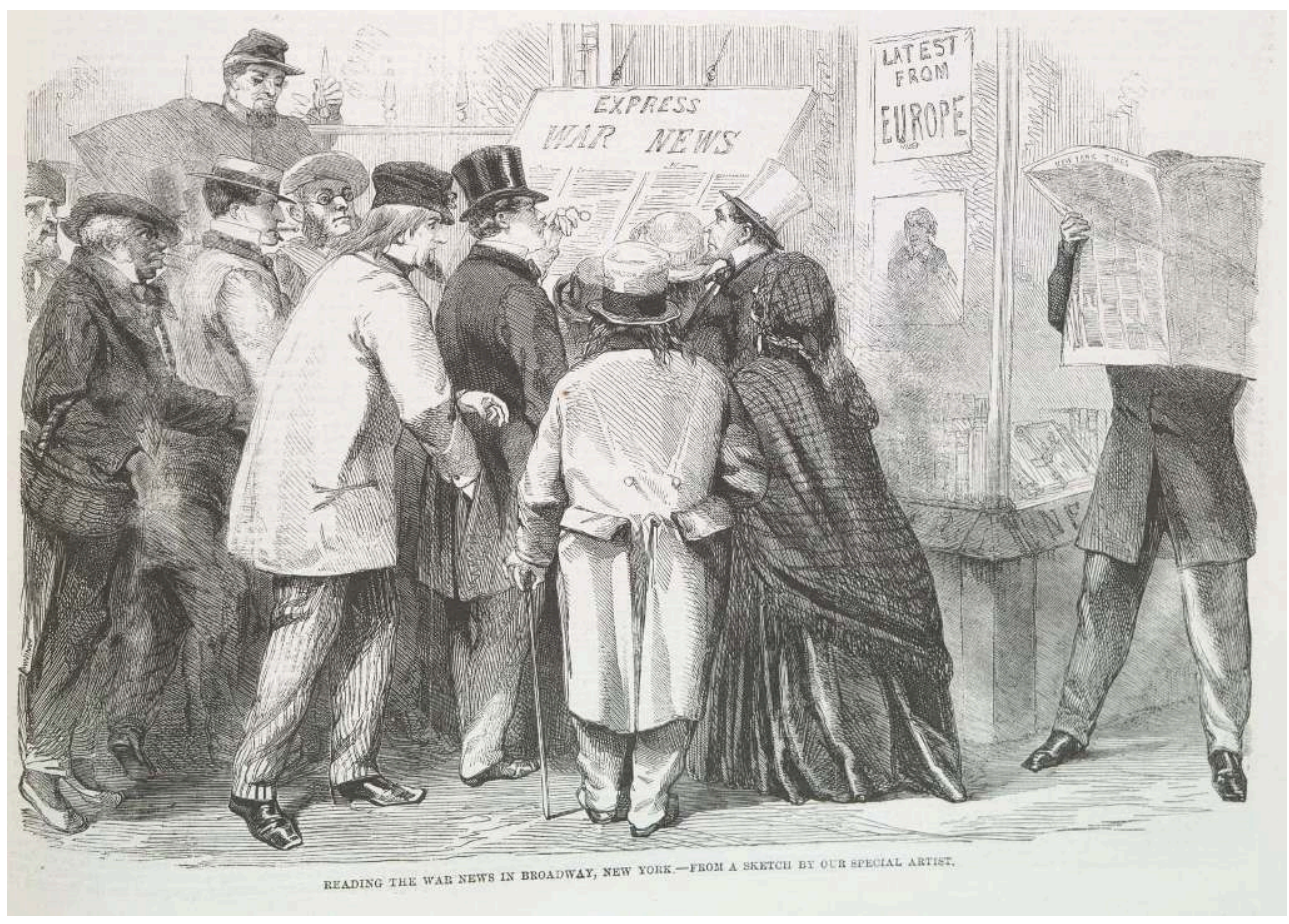

"Reading the War News," scene of New Yorkers reading the newspaper in the street during the Civil War. From the Illustrated London News. (15 June1861; public domain)

The US Civil War was a time of tremendous interest in what was going on in the newspaper because in the North at least, you could get reports on what was happening on the battlefield, very rapidly, through the press, because news was being reported by telegraph for the first time. That was very important to newspapers and to the readers, who could find out very quickly about their loved ones. 


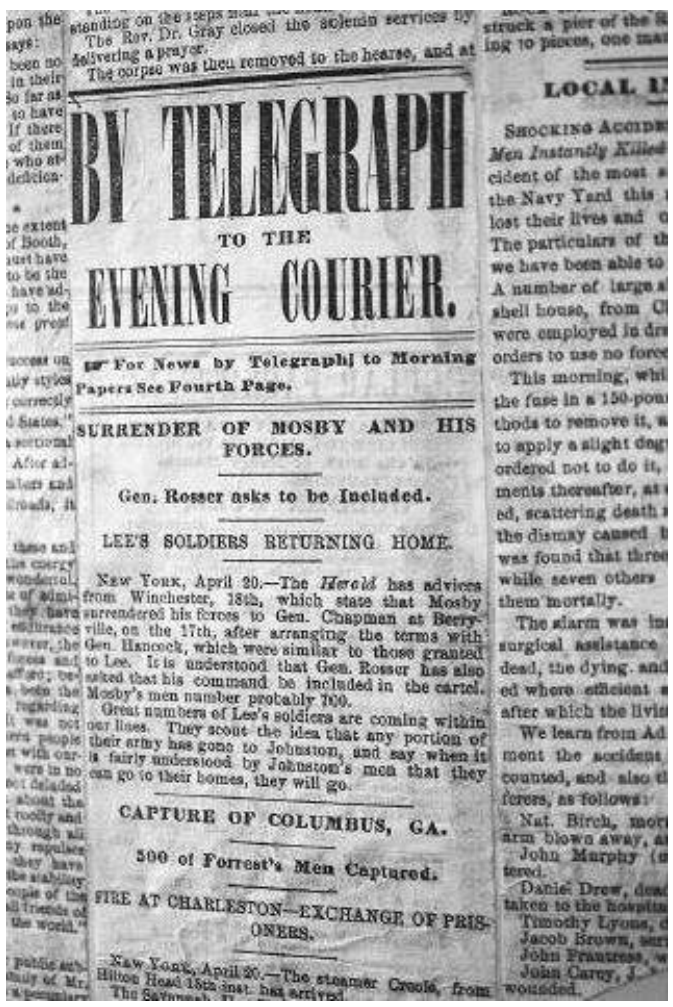

Civil War scrapbook item showing the prominence accorded to the fact that the news had arrived by telegraph. (Charles French, Civil War Scrapbooks, Massachusetts Historical Society.)

So people start reading the newspaper a lot more, and they start saving it, because they have a sense of living through tremendously important times. And the newspaper itself is part of how they've experienced that news. So even if they're living relatively near some battlefield, they would still be getting the news of it through the newspaper. In fact soldiers wanted copies of the newspaper too. The scrapbook becomes that record of not only, "here's what the news is," but "here's how I learned about it, and I'm saving that." People made scrapbooks also of poetry that moved them during the war. There was a lot of poetry in the newspaper and poetry of grief is an important part of these scrapbooks. They would sometimes write someone else's name next to a poem that moved them or apply something that was really about someone else to someone that mattered to them. This was a way of feeling together with other people in the country, as one scrapbook maker put it. They all felt this common grief and reading it together was part of feeling it together.

CP: Do you find that people included a lot of visuals in the scrapbooks?

EG: Not so much. I think partly because people cut up the daily press, which was less illustrated at the time. In the Civil War era papers, sometimes there are maps; some were more dedicated to that, have lots of images or maps, but the most heavily illustrated press was the weekly press, and maybe to some degree the monthly press, works like Harper's Weekly or Leslie's Weekly. I think people were less likely to cut those up, they were more likely to save them whole. On the other hand, my own interest was in the writing and in what they did with that material, so I was less likely to follow up on scrapbooks that were all pictures.

CP: You've chosen to focus on minorities, for example women and African Americans. I was struck when I read the book by the fact that making scrapbooks was a form of 
activism. Could you give a couple of examples of the way women activists used scrapbooks to provide a different picture of the women's rights movements, or the way African Americans used them to write their own history?

EG: I have a chapter on African American scrapbooks and one on women's rights scrapbooks, and those two topics also spill over in other chapters. Again, it was a democratic kind of archive, because it was so cheaply available. The newspaper was full of valuable important information that was going by too fast-this was a general sense that everybody suffered from, so many people thought of this as a reason to make scrapbooks. There were relatively few books about African American history appearing at that time, as you know from your own research; most people didn't have them and yet there was a lot in the newspapers. Now, it was often insulting since the white press was often either patronizing or insulting towards black people and mostly the scrapbooks that black people made are made from the white press. Now why is that? You would think that's sort of strange or accommodationist of black people to be picking up on these white newspapers. But the black press was weekly or monthly; there were no black daily newspapers, which meant that what we think of as the public sphere of print was essentially white. I have seen articles from black papers in black scrapbooks, but I think by and large people may have saved the whole paper, because I've seen some whole papers pasted in also.

There are a number of black scrapbook makers who made hundreds of scrapbooks. And those are all pretty amazing. And just the project itself was pretty amazing. Most of the scrapbook makers did not generally write anything in their books. There's one black scrapbook maker who does write occasionally in his book, and he's an interesting case. His name is John Wesley Cromwell, and he was a newspaper editor at one time, but during the period that he was not editing a newspaper, he kept a scrapbook.

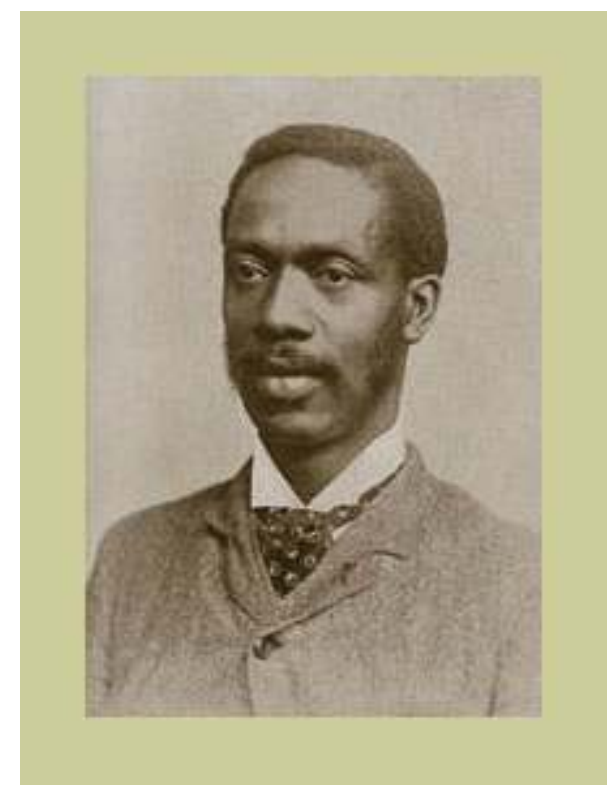

John Wesley Cromwell, editor, writer, lawyer, historian, and scrapbook maker (public domain).

And his scrapbook has this interesting way of speaking back to the white press. One way it speaks back is in his marginal comments. There's an obituary for a man who saw his father, Thomas Gorsuch of Pennsylvania, killed while the father was trying to suppress an insurrection of escaped slaves in Christiana, Pennsylvania. And the 
article is written in that style from the 1890s of sentimentality about the plantation South, everybody was wonderful to each other, slaves were happy. And then it talks about how the ex-slaves who were involved in the rebellion were accused of treason and brought to trial. Two of them were freed because they were ill and the whites were so lenient that they let them out, and then they lived to be in their 90s. So there's a sense of all those lenient white people. Cromwell annotates this clipping in a totally different way, there's a long note running along the side of it and he says, my father told me about this incident, and he said that bishop Nazrey prayed for them-a black bishop in the African Methodist Episcopal Church-he prayed that the testimony of the accusers would be confused so that they would be acquitted, and it happened just as he prayed. The story in the newspaper is a sentimental story about a white son and his losing his father, but Cromwell changes it into a totally different story of transmission of a black story of faith, of struggle, and a way of understanding history that his ex-slave father transmitted to him. He puts that in his scrapbook and that becomes a record. And there are traces in the scrapbook that he shared that with other people, because there are various notes that seem to be for other people to see. In this way, it's a way of teaching people how to read the newspaper, that there are other stories underneath it, and that you can learn something about activism and about reading against the grain of the white press. So the fact that it was the white press they were clipping becomes important, too. And there are other black scrapbooks in which people save stories about lynching. That was again a way of collecting information to share so as not to be completely flattened and dispirited by what was going on in the country.

CP: One last question: your work has triggered a very lively debate about scrapbooks and their use by scholars. You speak about the problems of conservation, especially in institutions that don't have a lot of money. Do you think that Writing with Scissors will lead to an increased effort of conservation and possibly cataloging by those institutions which hold them?

EG: I hope so. It's not going to get them any more money than they have, but I know for example that Penn State is now working with Cheyney University in Pennsylvania to try and digitize the William Henry Dorsey scrapbooks-an African American man who made 400 scrapbooks-and I hope that that works, because Cheyney had to stop short of their microfilming the scrapbooks years ago when they ran out of money. 


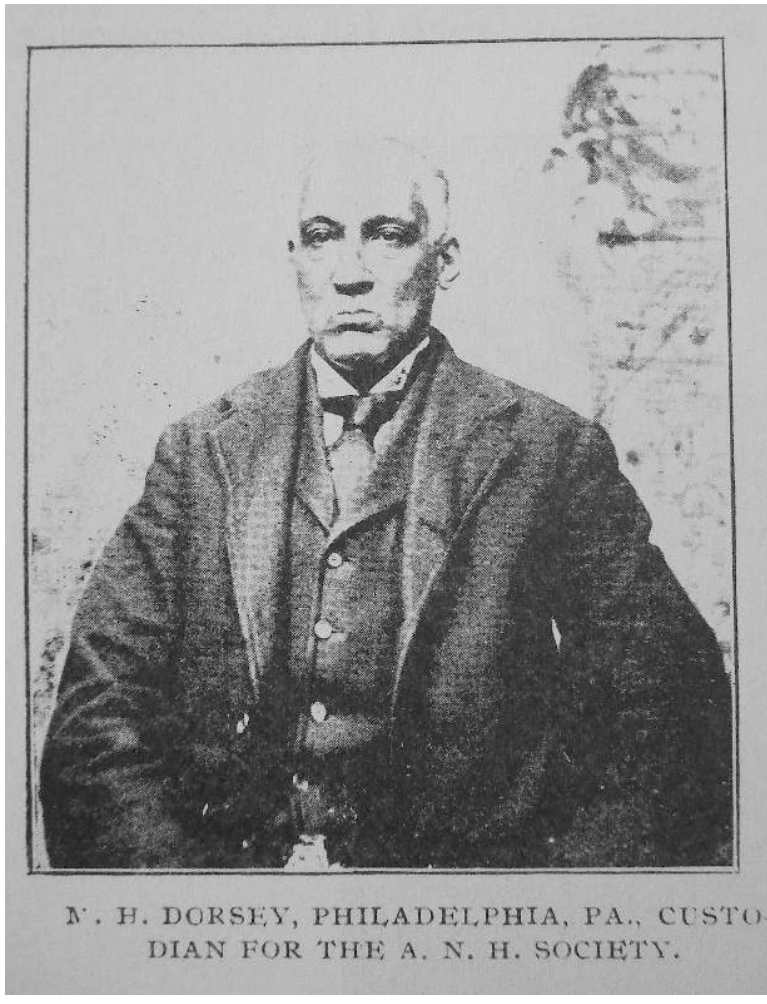

William Henry Dorsey, collector and historian. His 400 scrapbooks were used by WEB DuBois in writing The Philadelphia Negro, and more recently mined by historian Roger Lane for William Dorsey's Philadelphia and Ours. This picture shows him in his role as Custodian of Documents for Philadelphia's Negro Historical Society. (H.H. Wayman, "The American Negro Historical Society of Philadelphia and Its Officers," Colored American Magazine, February 1903, 294) (public domain)

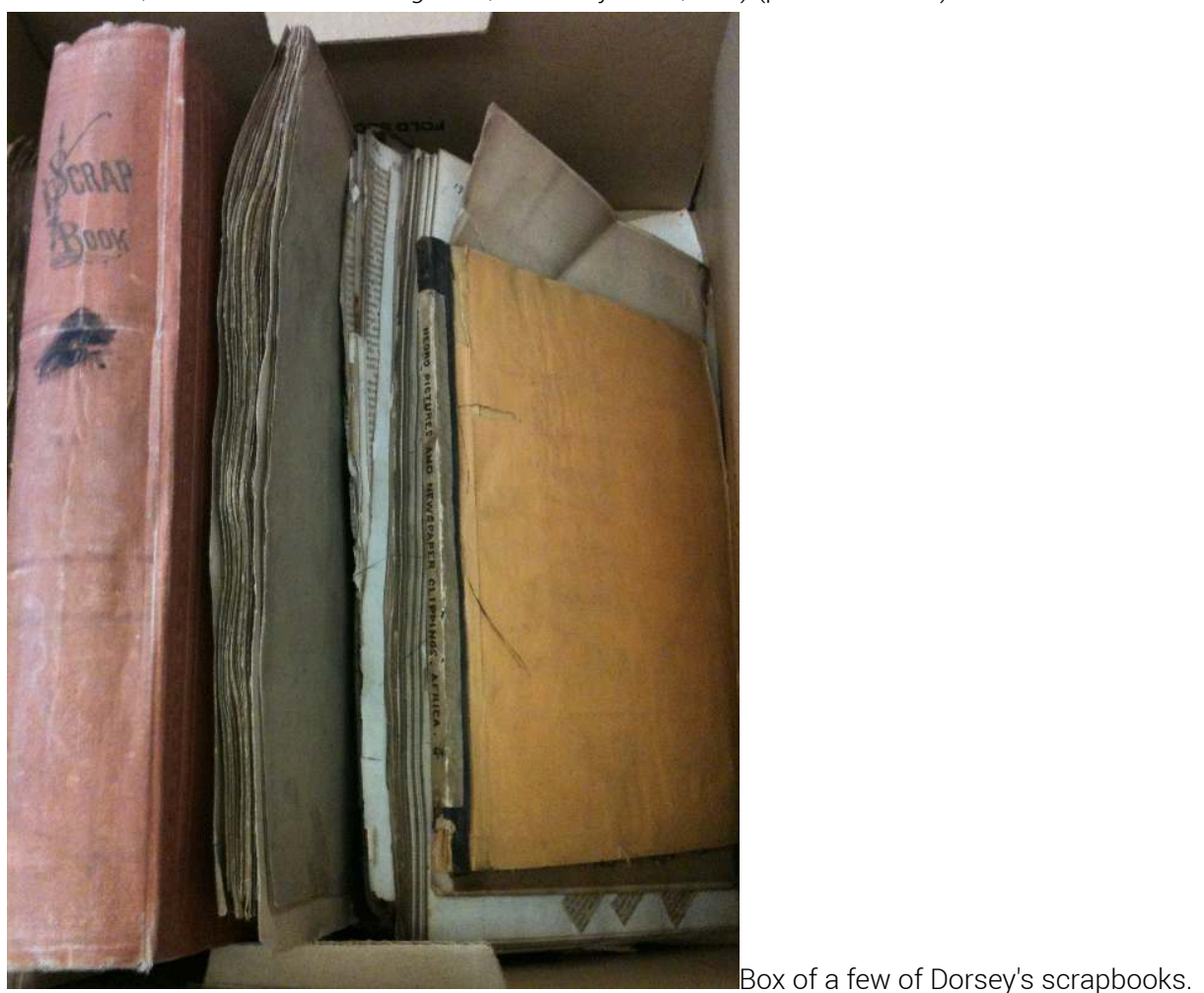

(Photograph from Penn State University Dorsey scrapbook blog, https://dorseyscrapbooks.psu.edu/? $\mathrm{p}=34$ 
Certainly a digital edition would be much better, but the scrapbooks themselves are crumbling. The problem as you get into the 1880s you get high-acid paper. Scrapbooks are a real nightmare for conservators, because they are mixed materials, their mucilage is often dark, and hard to read through. There is a physical problem of conserving them but also the fact that for a long time historians have understood scrapbooks as just a kind of backing or container for a particular newspaper article that they wanted to use and they've used the articles within scrapbooks. They haven't very much considered the scrapbook as a created work, as something that someone has constructed, and where the layout might tell you something about the maker's thoughts or where the arrangement and the choice of clippings will tell you something about who made it and why, and where there's a conversation going on between the maker's interests and the stuff they've collected. Now that people are seeing it in that light, I hope they'll save them more. Once you really understand that these are constructed books that have stories to tell through how they're created on the page, and as more people start using them with that in mind, I think then we'll see more attention to figuring out how to conserve them.

$\mathrm{CP}$ : Thank you very much.

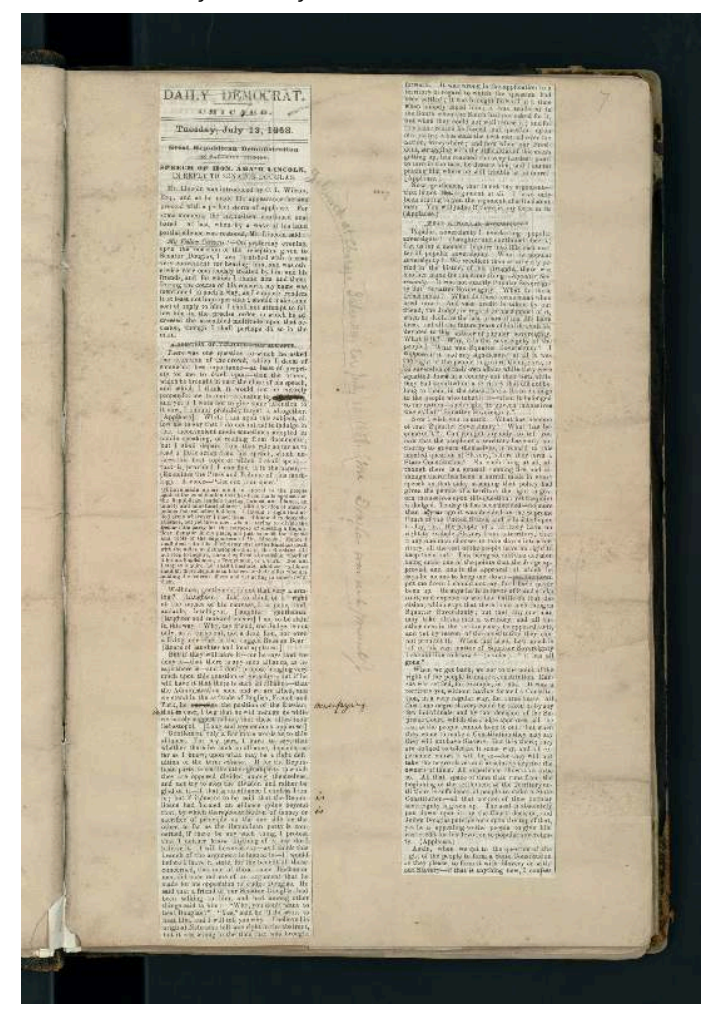

A page from Abraham Lincoln's scrapbook on his 1858 debates with Stephen Douglas, from the Library of Congress website: http://www.loc.gov/exhibits/treasures/trm124.html 

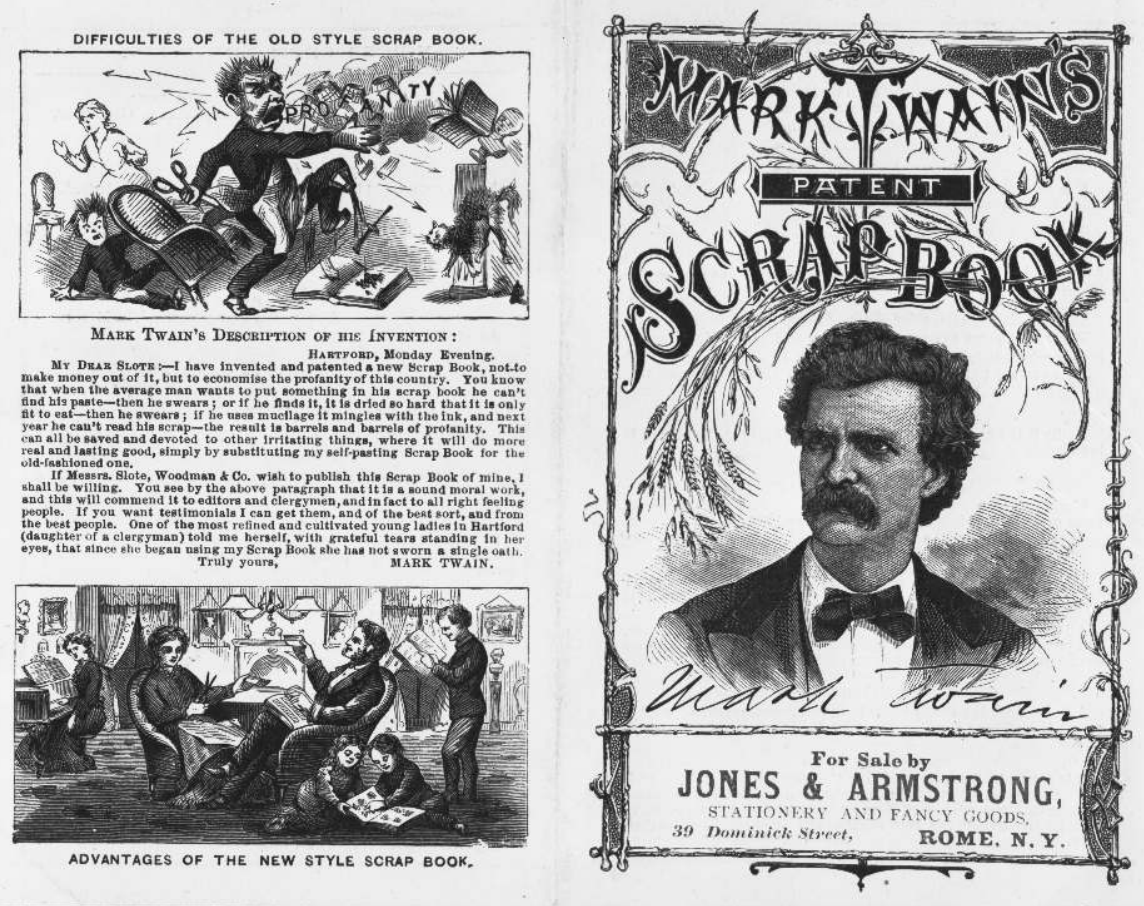

Mark Twain invented a scrapbook that did not require glue. He marketed it as a morally purifying invention that would save on profanity when the gluepot could not be found. His humorous ads drew much attention, and were freely reprinted. (Public domain.)

INDEX

Subjects: Trans'Arts

\section{AUTHOR}

\section{CLAIRE PARFAIT}

Université Paris 13 